\title{
ПРОБЛЕМА ДИФЕРЕНЦІАЦЇ̈ СКЛАДНИХ РЕЧЕНЬ В АСПЕКТІ ТЕОРІЇ ПЕРЕХІДНОСТІ
}

У статті зроблено аналітичний огляд теоретичних конщепџій вивчення різних типів складного речення в традиційному і новітньому мовознавстві. Окреслено класифікаційні засади типології складнопідрядних, складносурядних та безсполучникових речень. Концепції вивчення складнопідрядних речень об'єднано в чотири групи залежно від загальних підходів до з'ясування їхньої сутності: логікограматична, формально-граматична, структурно-семантична $i$ функційна класифікачії. 3'ясовано, щзо типологія складносурядних речень трунтується на врахуванні особливостей їхньої формально-граматичної, семантико-синтаксичної та комунікативної організащії. Зауважено, щуо безсполучникові речення логічно аналізувати на основі загальновизнаних у сучасному мовознавстві теоретичних засад складного речення, зважаючи на семантико-синтаксичні відномення між предикативними частинами. Обгрунтовано дієвість структурно-семантичного підходу для опису складних речень в аспекті теорії перехідності.

Ключові слова: складне речення; складнопідрядне речення; складносурядне речення; безсполучникове речення; логіко-граматична класифікачія; формальнограматична класифікація; структурно-семантична класифікація; функиійна класифікація; теорія перехідності; синкретичні складні речення.

\section{Шитик Л. Проблема дифференциации сложных предложений в аспекте} теории переходности.

В статье сделан аналитический обзор теоретических концепций изучения различных типов сложного предложения в традиционном и новейшем языкознании. Oпределены классификаччионные основь типологии сложноподчиненных, сложносочиненных и бессоюзных предложений. Концепции изучения сложноподчиненных предложений объединены в четыре группь в зависимости от общих подходов к определению их сущңности: логико-грамматическая, формальнограмматическая, структурно-семантическая и функииональная классификации. Выяснено, что типология сложносочиненных предложений основывается на учете особенностей их формально-грамматической, семантико-синтаксической $u$ коммуникативной организации. Констатирована иелесообразность анализа бессоюзных предложений на основе общепризнанных в современном языкознании теоретических основ сложного предложения, учитывая семантико-синтаксические отношения между предикативными частями. Обоснована действенность структурно-семантического подхода для описания сложных предложений в аспекте теории переходности.

Ключевые слова: сложное предложение; сложноподчиненные предложения; сложносочиненные предложения; бессоюзные предложения; логико-грамматическая классификация; формально-грамматическая классификаџия; структурносемантическая классификация; функциональная классификация; теория переходности; синкретические сложные предложения. 
Shytyk L. The problem of differentiation of component sentences in terms of the theory of transition.

The article is an analytical review of theoretical concepts of studying various types of component sentences in traditional and contemporary linguistics. Classification principles of typology of compound, complex and asyndetic sentences are outlined. Concepts of studying compound sentences are combined into four groups based on common approaches to definition of their nature: logical and grammatical, formal and grammatical, semantic and structural and functional classification. It was found out that the typology of complex sentences is based on consideration of peculiarities of their formal-grammatical, semanticsyntactic and communicative organization. It is noted that asyndetic sentences should be logically analyzed on the basis of universally accepted in modern linguistics theoretical foundations of a component sentence, taking into consideration the semantic-syntactic relations between predicative parts. The validity of the structural and semantic approach to description of component sentences in terms of the theory of transition is proved.

Keywords: component sentence; compound sentence; complex sentence; asyndetic sentence; logical and grammatical classification; formal and grammatical classification; structural and semantic classification; functional classification; theory of transition; syncretic complex sentences.

Складне речення, 3 огляду на різноплановість будови та багатоаспектність функціювання, належить до тих феноменів, які спричинюють різне тлумачення його типологійних характеристик. Це зумовлено, з одного боку, неоднаковими принципами кваліфікації, а 3 іншого - неадекватними підходами до 3'ясування місця і статусу предикативних одиниць - компонентів цілісного утворення [11, с. 319].

Характеризуючи особливості класифікації мовних одиниць, В. В. Щеулін наголошує на наявності частки суб' єктивізму в типологійних описах: класифікацію мовних одиниць, подібно до будь-якої лінгвістичної гіпотези чи теорії, можна витлумачити як специфічно суб'єктивне («наше») відображення заданого для пізнання. Це означає, що класифікаційна побудова стосовно мовного матеріалу завжди евристична, оскільки потребує чогось, що здатне в об'єктивно окреслених межах пояснити всю складність наявних фактів [23, с. 23].

Теоретичним підгрунтям дослідження складного речення постали методологічні засади східнослов'янського мовознавства, відображені в класичних теоріях дослідників російської мови (М. В. Ломоносова, О. Х. Востокова, М. І. Греча, Ф. І. Буслаєва, О. О. Потебні, П. Ф. Фортунатова, Д. М. Овсянико-Куликовського, О. М. Пєшковського, О. О. Шахматова, В. О. Богородицького) і в працях українських синтаксистів (С. Й. Смаль-Стоцького, В. І. Сімовича, К. Т. Німчинова, М. Ф. Наконечного, О. Н. Синявського, С. С. Смеречинського та ін.). Фундаторами сучасних синтаксичних досліджень є: В. В. Виноградов, М. С. Поспєлов, В. А. Бєлошапкова, Н. С. Валгіна (у царині вивчення російської мови), О. С. Вержбицький, І. Г. Чередниченко, Б. М. Кулик, 
Є. В. Кротевич, О. С. Мельничук, А. П. Грищенко, С. П. Бевзенко, I. Р. Вихованець, К. Г. Городенська, I. І. Слинько, Н. В. Гуйванюк, М. Ф. Кобилянська, А. П. Загнітко, К. Ф. Шульжук, В. М. Ожоган, М. В. Мірченко, І. Я. Завальнюк, Р. О. Христіанінова та ін. (у сфері дослідження української мови). Типологія складних речень теоретично обгрунтована в таких академічних виданнях, як «Курс сучасної української літературної мови» (1951), «Сучасна українська літературна мова: Синтаксис» (1972), «Русская грамматика» (1980), «Украинская грамматика» (1986).

Мета статті - зробити аналітичний огляд представлених у мовознавстві концепцій вивчення складного речення. Досягненню поставленої мети сприятиме реалізація таких завдань: узагальнити проблеми сучасного стану теоретичного опрацювання різних типів складного речення; окреслити класифікаційні засади типології складнопідрядних, складносурядних та безсполучникових речень; обгрунтувати дієвість структурно-семантичного підходу для опису складних речень в аспекті теорії перехідності.

Здобутки і непослідовність теорії складного речення відображає передусім типологія складнопідрядних речень. У східнослов'янському мовознавстві сформувалися три принципи класифікації складнопідрядних речень: логіко-граматичний, в основі якого лежить уподібнення складнопідрядного речення до простого речення, а підрядних частин - до членів простого речення (підметові, присудкові, додаткові, означальні, обставинні) (О. Х. Востоков, М. І. Греч, Д. М. Овсянико-Куликовський, Є. В. Кротевич, Ф. І. Буслаєв, Б. М. Кулик та ін.); формальнограматичний, грунтований на характеристиці засобів зв'язку частин складнопідрядних речень, за яким диференційовано складнопідрядні речення зі сполучниками і сполучними словами (О. М. Пєшковський, М. Ф. Наконечний, О. Н. Синявський та ін.); структурно-семантичний, згідно з яким ураховують структурні й семантичні співвідношення між головною та підрядною частинами. Елементи структурно-семантичного опису складнопідрядних речень $є$ в працях П.Ф. Фортунатова i O. О. Шахматова. В. О. Богородицький першим погрупував складнопідрядні речення за комбінованими критеріями, висловивши думку про те, що, класифікуючи підрядні речення, потрібно враховувати: 1) чого речення стосується; 2) якими формальними засобами пов'язане; 3) які значеннєві відтінки виражає [3, с. 230]. Цими критеріями започаткований структурно-семантичний принцип класифікації складнопідрядних речень, який був визнаний у синтаксичній науці другої половини XX ст. та в XXI ст. (М. С. Поспєлов, В. А. Бєлошапкова, І. Г. Чередниченко, С. П. Бевзенко, І. Р. Вихованець, К. Г. Городенська, М. У. Каранська, А. П. Загнітко, М. В. Мірченко, К. Ф. Шульжук та ін.). 
Засади структурно-семантичної класифікації першим найповніше схарактеризував М. С. Поспєлов, поділивши складнопідрядні речення на одночленні, підрядна частина яких залежить від слова головної частини, та двочленні, у яких підрядний компонент загалом пов' язаний із головним [18, с. 23-28]. Незважаючи на деякі вади цієї класифікації, концептуальна думка М. С. Поспєлова про те, що складнопідрядне речення потрібно кваліфікувати як єдине ціле і що ці речення варто поділяти на два основні типи, вплинула на багатьох дослідників синтаксису. Пошуки нових підходів до класифікації складнопідрядних речень засвідчили важливість ідеї М. С. Поспєлова про одно- і двочленні речення, іiі концептуальну переконливість, що дало змогу В. А. Бєлошапковій запропонувати поділ складнопідрядних речень на розчленовані і нерозчленовані. Цей поділ грунтується на трьох принципах: власне-структурному, структурносемантичному та власне-семантичному [1, с. 204-205].

Такий підхід до класифікації складнопідрядних речень послугував підгрунтям для формулювання основних положень структурносемантичного синтаксису, ідеї якого реалізують у сучасному українському й російському мовознавстві. У сучасній українській мові, зазначає А. П. Загнітко, складнопідрядні речення можуть бути схарактеризовані: 1) за типами зв'язку; 2) за призначенням підрядної частини щодо головної; 3) за комунікативною перспективою, у якій розгортається висловлюваний у них зміст [11, с 385].

Синтаксичні дослідження останніх десятиліть спираються на нові підходи до опису складнопідрядних речень: функційний [2], функційносемантичний [6], функційно-категорійний [21], типологійний [15], різні стратегії оформлення підрядності [14] тощо.

Логічно витриманою $є$ класифікація I. Р. Вихованця, що враховує формально-синтаксичні i семантико-синтаксичні особливості складнопідрядних речень. Відповідно до ознаки залежності підрядної частини від головної загалом чи від опорного слова, учений поділив складнопідрядні речення на два типи: 1) неприслівні, диференційовані на два підтипи: а) власне неприслівні складнопідрядні речення, у яких залежність підрядної частини від головної загалом виражають семантичні підрядні сполучники; б) неприслівно-кореляційні складнопідрядні речення, де залежність підрядної частини від головної загалом передають анафоричні сполучні слова, семантично співвідносні з усім змістом головної частини; 2) прислівні, розподілені на два підтипи: а) прислівні валентно-поєднані складнопідрядні речення, у яких обов' язкову наявність підрядної частини зумовлює семантико-синтаксична валентність опорного слова головної частини; б) прислівні невалентно-поєднані складнопідрядні речення, де наявність підрядної частини спричинюють граматичні особливості опорного слова головної частини [5, с. 4-8]. 
Семантико-синтаксична класифікація складнопідрядних речень I. Р. Вихованця грунтована на семантико-синтаксичних відношеннях між підрядною і головною частинами, що вможливило виокремити такі типи та підтипи: 1) адвербіальні складнопідрядні речення (підтипи: часові, причинові, наслідкові, мети, умовні, допустові, порівняльні, відповідності); 2) атрибутивні складнопідрядні речення; 3) субстанціальні складнопідрядні речення (семантико-синтаксичні підтипи: з'ясувальнооб'єктні придієслівні складнопідрядні речення, порівняльно-об' єктні прикомпаративні складнопідрядні речення, локативні придієслівні складнопідрядні речення); 4) ототожнювальні складнопідрядні речення, диференційовані на: субстанціально-ототожнювальні, атрибутивноототожнювальні, локативно-ототожнювальні, темпоральноототожнювальні; 5) супровідно-поширювальні складнопідрядні речення [Там само]. ${ }^{1}$

Нам імпонує виокремлення в самостійну групу складних речень, одна 3 предикативних частин яких ужита в позиції підмета, т. зв. складних речень із взаємозалежними частинами [6, с. 345-347; 21, с. 97-104]. Однак у функційно-семантичній класифікації І. Р. Вихованець відводить таким конструкціям периферію складнопідрядного речення, мотивуючи це тим, що «із семантико-синтаксичного боку (за вербоцентричною теорією речення) семантико-синтаксична валентність предиката поширюється й на суб'єктну реченнєву позицію» [5, с. 7]. У типологійному описі синкретичних складних речень конструкції з підметовою частиною, яким властивий синкретизм семантико-синтаксичних відношень, логічно аналізувати окремо, використовуючи для їх номінації термін I. Р. Вихованця «складні речення із взаємозалежними частинами».

Поглиблюючи функційно-семантичну класифікацію I. Р. Вихованця, Р. О. Христіанінова пропонуе докладнішу формально-синтаксичну та семантико-синтаксичну типологію складнопідрядних речень. Дослідниця вибудовує ієрархію формально-синтаксичних типів (складнопідрядні речення типової формальної структури, катафоричні і приєднувальні), підтипів (конструкції 3 приреченнсвими, прислівними та опосередкованими підрядними частинами; конструкції симетричної й асиметричної структури) i різновидів складнопідрядних речень (складнопідрядні речення з підрядними частинами валентного характеру та $з$ валентно не зумовленими частинами); у межах кожного формальносинтаксичного типу виокремлює семантико-синтаксичні класи, підкласи й різновиди [21, с. 10].

Вартий уваги функційний підхід до аналізу складнопідрядних речень, оскільки він науково витриманий і позбавлений деяких вад структурно-

\footnotetext{
${ }^{1}$ Див. інший підхід до класифікації складнопідрядних речень: [6, с. 313-340 та ін.].
} 
семантичної класифікації, однак у річищі теорії перехідності типологійний опис синкретичних складнопідрядних речень доцільно виконувати на підставі структурно-семантичного принципу. Погоджуємося 3 авторами «Синтаксису сучасної української мови: Проблемні питання», які вважають достатніми підстави «поділяти складнопідрядні речення з урахуванням характеру пояснення підрядними частинами головних, відношень між головними і підрядними частинами, особливостей моделей складних речень і засобів їх створення сполучників, відносних слів, співвідносних слів, позицій підрядних частин тощо» [20, с. 437]. Зважаючи на обгрунтованість такого поділу, у нашому дослідженні для створення типології синкретичних складнопідрядних речень прийнято як базову класифікацію за характером пояснення підрядними частинами головних, зокрема: нерозчленовані, розчленовані та $з$ ознаками нерозчленованих і розчленованих структур. У подальшій диференціації враховано характер синтаксичного зв'язку (прислівний, неприслівний (детермінантний, приреченнєвий), опосередкований, який у складнопідрядних реченнях виокремлює Р. О. Христіанінова [21, с. 14]), закономірності його вияву в структурі речення, а також особливості семантики підрядних частин.

Питання типології складносурядних речень також є дискусійним. Традиційно їх поділяли за сполучниками на три різновиди: єднальні, розділові, протиставні (Є. К. Тимченко, В. І. Сімович та ін.). Пізніше почали додавати пояснювальні та приєднувальні (О. С. Вержбицький, А. П. Грищенко та ін.). Проте такий підхід унеможливлюе створення досконалої класифікації з огляду на неврахування особливостей будови i значення складносурядних речень. На структурно-семантичних особливостях грунтується класифікація, запропонована В. А. Бєлошапковою. За будовою дослідниця поділяє складносурядні речення на два типи - незамкненої та замкненої структури, серед яких виокремлює структурно-семантичні розряди і семантичні різновиди [1, c. 215]. Цей підхід хоч і вможливив «довільні тлумачення», проте дав змогу виявити такі варіанти складносурядних речень, які раніше лишалися поза увагою дослідників.

Досягненням у вивченні складносурядних речень стало розмежування власне-єднальних i невласне-єднальних утворень, що пов'язане 3 усвідомленням специфіки складносурядних речень, причому до невласнеєднальних зараховано ускладнені єднальні значення відтінками різночасності, зіставлення та приєднання [19, с. 616].

Такої думки дотримуються й деякі українські дослідники, уважаючи невласне-єднальними реченнями ті, у яких єднальне значення ускладнене відтінком послідовності, причиново-наслідкової зумовленості, протиставлення, допустовості, приєднання тощо. Складники невласне- 
єднальних речень неоднотипні, нерівноцінні, тому, на відміну від складносурядних відкритої структури (власне-єднальних речень), їм властива незворотність частин, двочленний склад (за термінологією В. А. Бєлошапкової - закритість структури) [20, с. 606], структурнограматична замкненість. 3 огляду на названі ознаки до складносурядних відкритої структури логічно зараховувати лише власне-єднальні речення зі значенням одночасності.

У розділовому розряді виокремлюють семантичні різновиди несумісності (взаємовиключення) та чергування. Нам імпонує думка А. П. Грищенка про те, що розділовим складносурядним реченням зі значенням виключення властива структурно-граматична замкненість, оскільки основний зміст таких синтаксичних одиниць полягає в повідомленні про несумісні дії, із яких можлива за певних умов лише одна, але не обидві (або кілька) одночасно. На складносурядні речення зі значенням чергування не поширюється принцип кількісного обмеження, тому можна говорити про їхню структурно-граматичну незамкненість [9, c. 145]. Це дає підстави зарахувати до складносурядних відкритої структури власне-єднальні зі значенням одночасності та розділові із семантикою чергування.

Складносурядні речення відкритої і закритої структур виокремлює I. Р. Вихованець, розрізняючи в межах першого різновиду два структурносемантичні розряди - єднальні та розділові, причому перший представлений i безсполучниковими конструкціями. Складносурядні закритої структури дослідник поділяє на різновиди залежно від граматичної природи сполучників, зокрема на зіставні, протиставні, приєднувальні та градаційні; окремою групою вважає складносурядні речення закритої структури зі сполучником $i$, що «являють собою вторинні конструкції, утворені внаслідок дериваційної взаємодії з іншими типами речень» [6, с. 309]. Залежно від лексичного наповнення предикативних частин ці речення можуть передавати такі семантикосинтаксичні відношення: причиново-наслідкові, умовно-наслідкові, зіставні, протиставні та доповнення [Там само, с. 307-310].

Сучасні дослідження складносурядного речення грунтуються на врахуванні особливостей їхньої формально-граматичної, семантикосинтаксичної та комунікативної організації, а тому посутню увагу звернено на сполучні засоби як одиниці релятивної семантики, функційне призначення яких - «виражати відношення між предикативними частинами в складному реченні» [8, с. 9]; характер семантикосинтаксичних відношень, сформованих на основі взаємодії семантики компонентів складносурядного речення, виокремлення структурносемантичних типів категорії сурядності, особливостей ऑï структури та напрямів співвідношення 3 іншими синтаксичними категоріями [11, 
с. 338-353]; основні підходи до актуального членування складносурядних речень [7, с. 194-198] тощо.

Найбільш проблемними в класифікації складних речень $\epsilon$ безсполучникові утворення. Наявні розбіжності стосуються передусім статусу безсполучниковості як самостійної синтаксичної категорії, іiі граматичного обсягу, типології безсполучникових речень тощо.

У межах першого аспекту розрізняють три позиції: а) безсполучниковість виокремлюють поряд із сурядністю та підрядністю як самостійний тип $[17$, с. $344 ; 13$, с. $248-250 ; 9$, с. $6-7 ; 10$, с. $30 ; 22$, с. 343-353 та ін.]; б) безсполучниковість тлумачать як варіант сурядності чи підрядності $[16, \quad$ с. $470-472 ; \quad 24, \quad$ c. $101-105 \quad$ та ін.]; в) безсполучниковість вилучають із системи складного речення через власне-текстовий вимір безсполучникових поєднань (сполучень) простих речень $[19$, с. 634] чи кваліфікують їх як безсполучникові комунікати 3 однобічним та 3 двобічним відношенням частин, тобто як «особливі синтаксичні одиниці, що більшою чи меншою мірою співвідносні із складними сполучниковими реченнями, але не мають граматичних моделей та парадигм, які б створювалися сполучниками чи відносними словами» [20, с. 632].

Питання граматичних меж складного безсполучникового речення має тенденцію до розширення або до звуження. За першого підходу до безсполучникових зараховують усі складні речення, у яких відсутні власне сполучники, тобто й речення зі сполучними словами [4, с. 47-52]. Спроба звузити коло безсполучникових речень, що належить В. А. Бєлошапковій, має реальні лінгвістичні підстави. Безсполучникові речення відкритої структури введені до розряду складносурядних, серед яких наявні семантично тотожні конструкції [1, с. 235-236]. С. Г. Іллєнко пропонує чіткіше окреслити межі безсполучникового речення, не змінюючи його загального статусу, а відокремивши складне речення від явищ тексту [12, с. 15].

I. Р. Вихованець частину безсполучникових конструкцій зараховує до складносурядних (єднальні речення 3 часовими відношеннями) та до складнопідрядних (речення, співвідносні зі складнопідрядними з'ясувальними 3 підрядним сполучником що), а решту синтаксичних одиниць кваліфікує як складні безсполучникові речення 3 недиференційованим синтаксичним зв'язком між частинами [6, cc. 304-306, 321-322, 347-351].

У науковій літературі немає єдиного погляду і щодо конкретизації різновидів безсполучникових речень. Їх виокремлюють залежно від принципів класифікації, основних критеріїв тощо. Безсполучникові речення диференціюють переважно на два різновиди, які неоднаково номіновані: з однорідними і неоднорідними частинами [22, с. 346-353], 3 
однотипними та різнотипними (неоднотипними) частинами [11, с. 419-429], 3 однофункціональними i різнофункціональними предикативними частинами $[10$, с. 33-34], незамкненої і замкненої структури [1, с. 235-236 та ін.]. Б. М. Кулик, крім речень з однотипними та різнотипними частинами, виокремлює ще й третій різновид безсполучникові речення, другий компонент яких уточнює або один iз членів першої, або пояснює всю першу частину загалом [13, с. 267-271].

Диференціація безсполучникових речень за типом семантикосинтаксичних відношень також виявляє великий діапазон значень: перелічувальні (єднальні, часові), зіставно-протиставні, умовні, причинові, наслідкові (або причиново-наслідкові), допустові, часові, цільові, 3'ясувально-об'єктні, пояснювальні, приєднувальні (або пояснювально-приєднувальні, поширювально-приєднувальні) тощо.

Синкретичні утворення в системі безсполучникових речень логічно аналізувати на основі загальновизнаних у сучасному мовознавстві теоретичних засад складного речення, зважаючи на синтезовані семантико-синтаксичні відношення між предикативними частинами.

Отже, для типологійного опису складних речень в аспекті теорії перехідності логічно залучати структурно-семантичний підхід, грунтований на врахуванні їхніх формально-синтаксичних та семантикосинтаксичних особливостей. Перспективу подальших наукових пошуків убачаємо в створенні загальної класифікаційної моделі синкретичних складних речень та в наповненні їі конкретним мовним матеріалом.

\section{СПИСОК ВИКОРИСТАНОЇ ЛІТЕРАТУРИ}

1. Белошапкова, В. А. Современный русский язык. Синтаксис / В. А. Белошапкова. - М. : Высшая школа, 1977. - 248 с.

2. Беляев, Ю.И. Синтаксис современного русского литературного языка : [учеб.пособие для студ. филол. спец. пед. высш. учеб. заведений] / Ю. И. Беляев. - Херсон : Айлант, 2001. - 494 с.

3. Богородицкий, В. А. Общий курс русской грамматики / В. А. Богородицкий. [5-е изд., перераб.]. - М. ; Л. : Соцэкгиз, 1935. - 356 с.

4. Василенко, И. А. К вопросу о союзных и бессоюзных предложениях в русском языке / И. А. Василенко // Проблемы современной филологии. - М. : Наука, 1965. - C. 47-52.

5. Вихованець, I. Проблема класифікації складнопідрядних речень / І. Вихованець // Лінгвістичні студії : зб. наук. праць / [укл. : А. Загнітко (наук. ред.) та ін.]. Вип. 6. - Донецьк : ДонДУ, 2000. - С. 4-8.

6. Вихованець, I. Р. Граматика української мови. Синтаксис : [підручник] / І. Р. Вихованець. - К. : Либідь, 1993. - 368 с.

7. Вінтонів, М.О. Актуальне членування речення і тексту: формальні та функційні вияви : [монографія] / М. О. Вінтонів. - Донецьк : ДонДУ, 2013. 327 c. 
8. Городенська, К. Г. Сполучники української літературної мови : [монографія] / К. Г. Городенська. - К. : Інститут української мови ; Видавничий дім Дмитра Бураго, 2010. - 208 с.

9. Грищенко, А. П. Складносурядне речення в сучасній українській літературній мові / А. П. Грищенко. - К. : Наук. думка, 1969. - 156 с.

10. Дорошенко, С. І. Складні безсполучникові конструкції в сучасній українській мові / С. І. Дорошенко. - Х. : Вид-во при Харківському держ. ун-ті видавничого об'єднання «Вища школа», 1980. - 152 с.

11.Загнітко, А.П. Теоретична граматика української мови: Синтаксис : [монографія] / А. П. Загнітко. - Донецьк : ДонНУ, 2001. - 662 с.

12.Ильенко, С.Г. К вопросу об общейтипологиисложногопредложения / С. Г. Ильенко // Переходность в системе сложного предложения современного русского языка / [отв. ред. Н. А. Андрамонова]. - Казань : изд-во Казан. ун-та, 1982. - C. 10-17.

13. Кулик, Б. М. Курс сучасної української літературної мови. Синтаксис / Б. М. Кулик. - К. : Рад. школа, 1961. - Ч. ІІ. - 287 с.

14. Латышева, А. Н. К вопросу о классификации сложноподчинённых предложений: три стратегии оформления подчинения / А. Н. Латышева // Сложное предложение: традиционные вопросы теории и описания и новые аспекты его изучения : материалы науч. конф., 23-24 апр. 1998 г., Москва. М. : Русский учебный центр, 2000. - Вып. 1. - С. 86-94.

15. Падучева, Е. В. О семантике синтаксиса. Материалы к трансформационной грамматике русского языка / Е. В. Падучева. - [2-е изд., испр. и доп]. - М. : КомКнига, 2007. - 296 с.

16. Пешковский, А. М. Русский синтаксис в научном освещении / А. М. Пешковский. - [7-е изд.]. - М. : Учпедгиз, 1956. - 511 с.

17. Поспелов Н. С. О грамматической природе и принципах классификации бессоюзных сложных предложений / Н. С. Поспелов // Вопросы синтаксиса современного русского языка. - М. : Изд-во АН СССР, 1950. - С. 11-19.

18. Поспєлов, М. С. Складнопідрядне речення і основні особливості його будови / М. С. Поспєлов // Укр. мова і література в школі. - 1983. - № 1. - С. 23-28.

19. Русская грамматика : [в 2 т.] / [редкол. : Н. Ю. Шведова (гл. ред.) и др.]. - М. : Наука, 1980. - Т. 2. Синтаксис. - 709 с.

20. Слинько, I. I. Синтаксис сучасної української мови. Проблемні питання / І. І. Слинько, Н. В. Гуйванюк, М. Ф. Кобилянська. - К. : Вища школа, 1994. $670 \mathrm{c.}$

21. Христіанінова, Р. О. Складнопідрядні речення в сучасній українській літературній мові : [монографія] / Р. О.Христіанінова. - К.: Інститут української мови ; Видавничий дім Дмитра Бураго, 2012. - 368 с.

22. Шульжук, К. Ф. Синтаксис української мови : [підручник] / К. Ф. Шульжук. К. : Видавничий центр «Академія», 2004. - 408 с.

23. Щеулин, В. В. О классификации сложноподчинённых предложений / В. В. Щеулин. - Воронеж : Изд-во Воронежского ун-та, 1972. - 50 с.

24. Bauer J. Souřadné souvěti / J. Bauer // Kapitoly ze srovnávací mluvnice ruské a české. - Praha : Československá akademie věd. Sekce jazyka a literatury, 1961. V. II. - S. 101-105. 